\title{
From Movie to Design: Interpretation of "Passengers" in the Form of Basic Design Principles
}

\author{
Damla Atik [D \\ Trakya University, Faculty of Architecture, Edirne, Turkey (Corresponding author)
}

\begin{abstract}
Received: November 29th 2020, Revised: December 6th 2020, Accepted: December 7th 2020.
Refer: Atik, D., (2020), From Movie to Design: Interpretation of "Passengers" in the Form of Basic Design Principles, Journal of Design Studio, V.2, N.2, pp 173-181,

D. Atik ORCID: 0000-0003-3963-3844,

DOI: $10.46474 /$ jds. 833050 https://doi.org/10.46474/jds.833050
\end{abstract}

\begin{abstract}
Design is a tough process in which knowledge, skill, awareness, sophistication, inspiration, time and creativity should be brought together efficiently within artistic and aesthetic approach. Design education involves observing, researching, thinking, interpretation, designing and producing processes concordantly. Due to its unusual formation; students face difficulties while transforming intangible concepts into tangible products in basic design courses. An encouraging and inspiring teaching-learning process is required in this unique course. Conventional basic design education is structured on teaching the design elements and principles that make up a visual composition. Basic design curriculums of different departments are correlated with various branches of art and present interpretation diversity within students' applications and basic design studio experiences. It is aimed to make a contribution to the wide range of basic design course within a case study themed on cinema in this study. Regarding to experimental method and watching a movie, students designed three dimensional models representing their inferences. Interpretation diversity has been observed due to students' cognition, observation, ways of access to information and creativity. As a result, deductive thinking and visual depiction of the movie through basic design principles have resulted creative products and benefited students' teaching-learning process.
\end{abstract}

Keywords: Basic Design, Creativity, Design Education, Interpretation, Passengers the movie

\section{Introduction: About (Basic) Design Education}

According to Yürekli ve Yürekli (2004), design education is comprehensive with its complex and contradictory structure based on abstract concepts. The authors find it difficult to define, understand, classify and form this education because it is not obvious. Onur and Zorlu (2017) emphasize the purpose of design education in terms of revealing and developing the creative thinking potential of students. In addition to this, Ertok Atmaca (2014) states about learning to make benefit from design elements, creating a design language through two and three dimensional compositions and solving formspace relationship. Regarding to this, Canbakal Ataoğlu (2015) suggests that the basic design education essentially aims to create the optimum environment for the development of creativity and present new methods that will improve students' abilities to produce new and authentic solutions by purifying them from prior knowledge. In another words, San (2010) and Pazarlığlu Bingöl (2016) claim that basic design education is a process that brings the student's perception, impression, observation, research, connotation, invention, knowledge, evaluation and many other intellectual processes into a unique form with new regulations. Besides, Eysenck (1994) mentions that cognitive, personal and environmental variables are effective on creativity also. 
Creativity is the ultimate goal of the teachinglearning process. Smith et al. (1995) state that creativity includes the stages of producing and discovering within the framework of the individual's mental activities; this process can also be said as an intuitive thinking. This creative process includes the production of creative thinking, creative exploration, interpretation and product development according to them. The individual and cultural components of the designer are effective in the creative process at the same time. Alsaggar and Al Atoum (2019) mention that interests, intelligence and the effectiveness of senses vary. Thus, the students respond differently to the learning-teaching methods. Their commitments in the learning process depend on their experience and their interaction with each other and with their environment. Related to these approaches Ketizmen Önal (2011) gathered the main components that are effective in the emergence of creative product and thought under three main headings (Table 1). Alsaggar and Al Atoum (2019) believe that the more senses of perception are involved, the higher is the learning potential of the students; by reason of perception is the basis of learning and each student is unique. Besides, each product is an indicator of interpretation in basic design studios (Figure 1). Because, products are designed upon a given concept and by listening, watching and reading, observing or imagining experiences within cognition of basic design fundamentals in basic design applications (Atik, 2020). Similarly, Düzenli et al. (2017) who think that a practical and creative education approach should be followed in basic design courses, determined that the course have significantly contributed to creativity and learning process of students besides their ability of producing.

In the light of these, purposes of basic design courses are put forward finally, with its difficulties. Beşgen et al. (2015) mention the purposes as educating the personality, enabling to construct relation among design constructs and with environment through design and using the basic language of design. The basic design education in its centenary history, accepted the

Table 1. Components of creative product (Ketizmen Önal, 2011)

\begin{tabular}{ll}
\hline Cognitive variables & $\begin{array}{l}\text { Individual's intelligence } \\
\text { Knowledge level } \\
\text { Technical and special abilities }\end{array}$ \\
\hline & Political factors \\
Environmental variables & $\begin{array}{l}\text { Religious factors } \\
\text { Cultural factors } \\
\text { Socio-economic factors } \\
\text { Educational factors }\end{array}$ \\
\hline Personal variables & Individual's intrinsic motivation \\
& Belief system \\
& Creative capacity \\
\hline
\end{tabular}

Journal of Design Studio, v:2 n:2

Atik, D., (2020), From Movie to Design: Interpretation of "Passengers" in the Form of Basic Design Principles, 


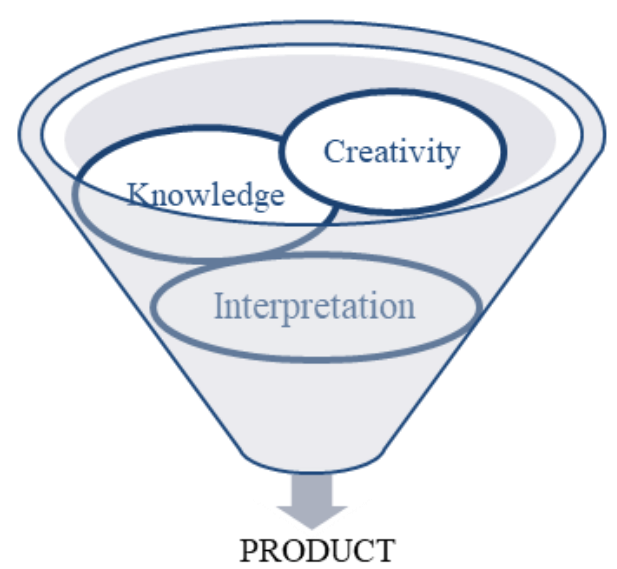

Figure 1. Production process in basic design studio (Atik, 2020)

visualization as a base, tried to systematize the presence of a visual language and developed methods according to this (Seylan, 2005). Aydinl (1996) suggests that basic design course is one of the most challenging courses for students in the first semester of university education as intuitive teaching methods are used. Kavas et al. (2016) draw attention to the difficulties which students face during the process of the basic design course. These difficulties are at the level of knowledge, skills and competence according to the authors (Table 2). This study intends to overcome these difficulties within a case study.

\section{Material and Method}

In Boucharenc's perception and practice (2006), the pedagogy of basic design promotes a holistic, creative and experimental methodology that develops the learning style and cognitive abilities of students with respect to the fundamental principles of design. Similarly, Soliman (2017) asserts that experimental learning is an important part of design education. It is important to produce methods that support connecting the abstractconcrete, to develop the imagination devoted to stimulate the creative design process and the creative thinking by experiences in the studio according to him.

Table 2. The difficulties in basic design course (Kavas, Erbaş, \& Danacı, 2016)

\begin{tabular}{lll}
\hline & $\bullet$ & Students are used to memorize the knowledge from \\
Knowledge & prior education style. \\
& - & Students must gain analytical and critical \\
& perspective. \\
\hline Skill & Students' incapability in using abstract language of \\
& design for understanding the environment and \\
& expressing new proposals should be improved. \\
\hline & It is about thinking through alternative solutions, \\
& deriving criteria of evaluation. \\
& It is about learning how to make selections among \\
& these alternatives and developing the selected \\
& alternative into a finished end product.
\end{tabular}

Journal of Design Studio, v:2 n:2

Atik, D., (2020), From Movie to Design: Interpretation of "Passengers" in the Form of Basic Design Principles, 
Basic design studio experiences and applications enable interpretation diversity within the themes of drawing, modeling, cinema, music, literature, apparel and fashion, creative drama and so on. For instance Zülfikar and Ertin (2014) have experienced creative drama method to abstracts concepts. The main theme of their experimental study was fictionalizing the movie "Skhizein" and interpreting it with body language to enrich the design through a workshop. The students produced alternative answers by critical
Beşgen and Köseoğlu (2019) have organized a "Cine-Design Workshop" as an exemplification of the potentials of the combination of two disciplines, cinema and architecture in a philosophical discussion.

Inspiring from these researches, an experimental method was followed relating to students' products in which design principles were used and the Passengers movie was chosen as the material in this study. The steps of the method are shown in Figure 2.

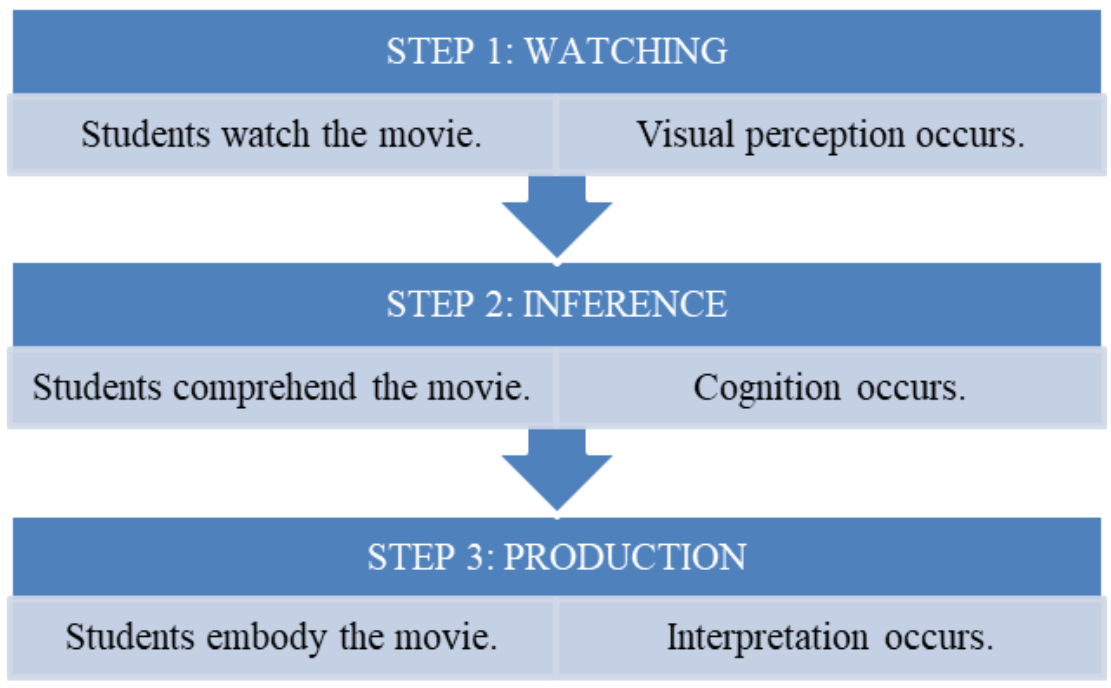

Figure 2. Method for the design process of the movie

thinking and realized a transformation process by images. Canbakal Ataoğlu (2015) has asked her students to analyze, interpret and design the given problem by creating two-dimensional abstract compositions first, and then transforming them into a concrete product and applying on the goods that are used in daily life; finally a street fashion show was organized. Bostanc1 et al. (2016) emphasized the necessity of music in terms of the development of visual perception, thinking, hand-eye-brain abilities of the individual who received basic design training, and activation of imagination-intuition powers. Atik (2020) has studied a literary text "Invisible Cities" by Calvino with her students in order to experience an evaluation method.
"Passengers" is a 2016 American science fiction romance film directed by Morten Tyldum and written by Jon Spaihts (2016). The film stars Jennifer Lawrence and Chris Pratt as Aurora Lane and Jim Preston, respectively, with Michael Sheen and Laurence Fishburne in supporting roles. The plot depicts two people who are awakened ninety years too early from an induced hibernation on a spaceship, transporting thousands of passengers, travelling to a colony on a planet in a star system sixty light years from Earth. The Avalon, a sleeper ship transporting 5,000 colonists and 258 crew members in hibernation pods, is on course to the planet Homestead II, a journey lasting 120 years. In the thirtieth year of the journey, an 
asteroid collision damages the ship and causes its computer to awaken one passenger, mechanical engineer Jim Preston 90 years early. Jim grows despondent and contemplates suicide until he notices a beautiful young woman named Aurora Lane inside her pod. Jim views Aurora's video file and is smitten with her. After struggling with the morality of prematurely reviving Aurora for companionship, therein robbing her of her future/planned life, he awakens her, letting her believe that her pod also malfunctioned. Over the next year, Jim and Aurora slowly grow closer, eventually falling in love with each other. Eighty-eight years later, the ship's crew is awakened on schedule, shortly before arrival at Homestead II. In the ship's grand concourse area they discover a huge tree, lots of trailing vines and vegetation, birds flying, and a cabin. Aurora's voice-over is reading her story, describing the wonderful life she and Jim had together on the Avalon (Figure 3) (URL 1, 2020).

\section{Case Study}

The case study was carried out at Trakya in both semesters. The instructor shares theoretical information with the students through written sources, visual samples and tangible materials in the theoretical session. In the practical session on the other hand, the students are asked for individual application using determined materials beforehand and make a presentation with either two or three dimensional product. Following the presentation of the products, the students get critique and instructor has feedback at the end of the sessions.

The instructor recommends and initiates the process of acquiring knowledge by related clues and basic concepts. The theoretical session is studied in an integral way with practical one (practical-theoretical integrity method). Avoiding from copy or imitation of earlier template studies, the vision of students is improved by offering modern samples (template studies method). The motivation and awareness of students are increased by the instructor with positive attitudes also (modern method). Besides, schematic, mechanics,
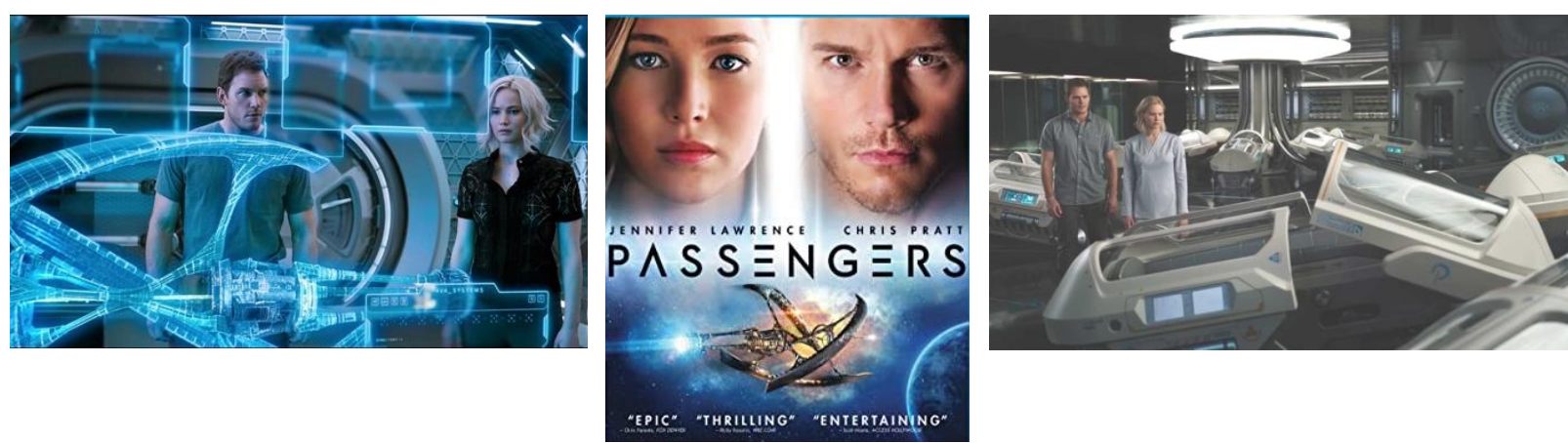

Figure 3. Passengers the movie (URL 2) (URL 3) (URL 4) in order

University, Faculty of Architecture, Department of Landscape Architecture in spring semester of 2018-2019 academic years. The curriculum of the course at the faculty involves design elements (point, line, form, size, color, value, pattern, direction, space) in Basic Design I and design principles (Gestalt theory, repetition, harmony, contrast, hierarchy, hegemony, balance) in Basic Design II. The courses are conducted within forty minutes for theoretical and two hours for practical sessions mental and perceptive tendencies are considered (multiple intelligence theory method) in basic design courses. The application session is enriched within visual and spatial intelligence by using colors, shapes, textures, images and other visual symbols. These methods are mentioned by Aypek Arslan (2012). In this case study differently from studio applications, a movie is chosen to study as an end of term assignment. 
Journal of

Design Studio

v:2 n:2 December 2020

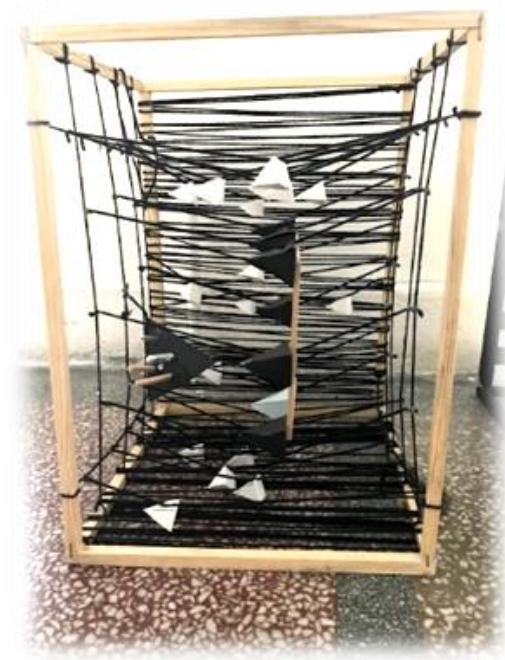

1

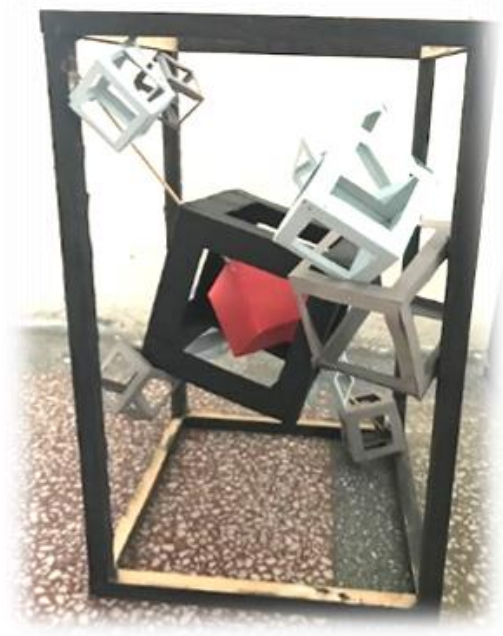

4

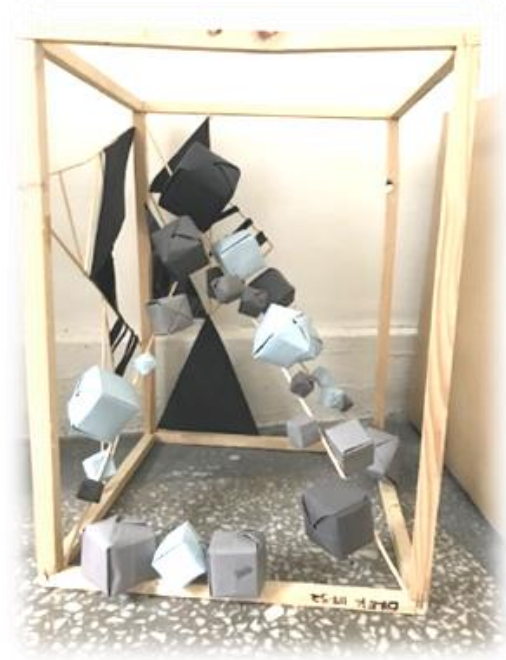

2

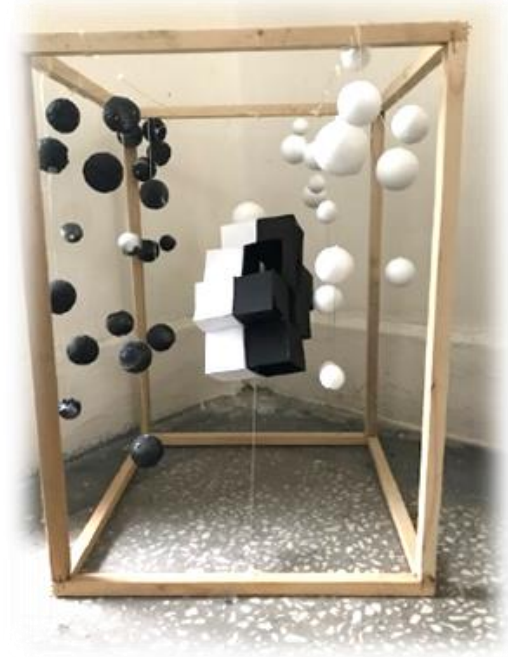

5

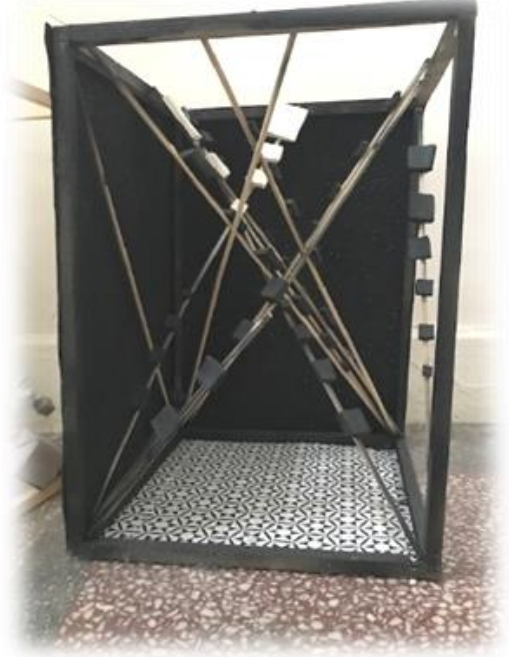

3

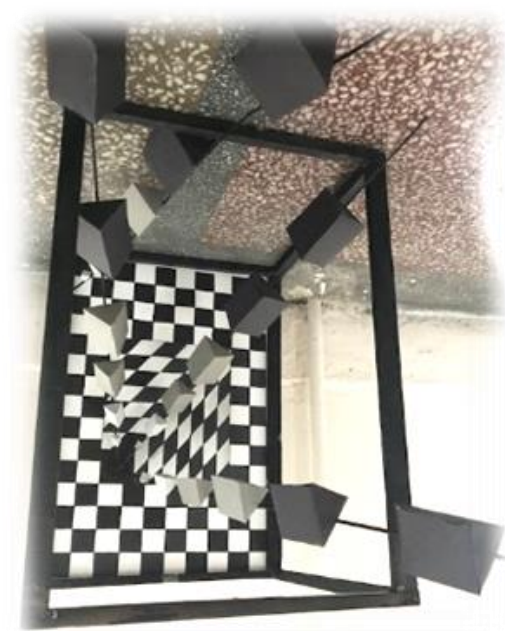

6

Figure 4. Products - Presentation of "Passengers" in the form design principles

The students were asked to watch the movie Passengers first and then to make a presentation with a product that reflects their creativity, interpretation and visual language. The students were expected to make a description about the movie depending on their inferences and using design principles in a wooden frame with size of $30 \times 30 \times 40 \mathrm{~cm}$; size of the shapes, materials and color usage were not limited.

\section{Findings}

Six proper products reflecting different principles were chosen among the products which the students delivered (Figure 4). Each of the products was based on a theme that got inspired from the movie.

The principle of first product was "Balance". The balance between the planned voyage of the 
ship and unknowns/handicaps of outer space was intended to be shown within the order of the ropes and usage of colors. The second product has reflected the usage of "Harmony" principle based on a statement that the characters who have sought out solutions to the problems encountered on the ship and has put everything in order as seen with the gray toned cubes. The cubes which are getting bigger and bigger in the third product represent the destination oriented progress and ship's arrival over the years. Thus, the third product pointed out "Hierarchy" principle. The fourth product has reflected another principle: "Hegemony". This is the hegemony of the ship with red cube and the main characters of the story with black hollow cube. The principle of fifth product was "Contrast" with the exact usage of black and white which were representing problems and solutions besides, gender difference. The statement has focused on the main characters being two different parts of a whole depending on being man and woman. "Repetition" principle has been used in the sixth product and it has depicted the ship's voyage and space spatially. The usage of chessboard and equal sized forms has explained the end that has been reached by repeating each other every year both before awakening and after death.

\section{Results and Discussion}

Based on various statements related to the movie, it has been seen that different principles could be used. The students have watched the movie; they have encountered the main theme, the message to be given, the images and the metaphors of the movie referring to the first step of the method of the study shown in Figure 2. Following this visual perception, when they have comprehended the movie, they made their inferences; step two has been actualized. Finally as the third step of the method, students have embodied the movie and the products have been shown out within students' cognition and interpretation. The results of the study within discussion of literature are put forward below:

- The design process can be fed by visual, intellectual and spiritual aspects of cinema. Referring Pallasma's (2008) statement "cinema with its temporal and spatial structure is the closest art branch to architecture", the relationship between cinema and landscape architecture were experienced in the context of design education.

- Cinema defines a virtual architectural space and reproduces the existing architectural spaces in its own virtual universe (Tanyeli, 2001). Although the students were not expected to make an architectural spatial design in this study contrary to Beşgen and Köseoğlu's (2019); the students made descriptions of the movie impressed by spatial expressions.

- The difficulties that students face at levels of knowledge, skill and competence (Kavas, Erbaş, \& Danac1, 2016) in design education have been overcome with the guidance of the method that has been used in this study. Since the students had a movie as a study material, they have enjoyed basic design more than the other courses.

- Since the students need to be encouraged for thinking, designing and producing (Atik, 2020), the students determined their own visual and conceptual language without any critique and advice.

- Düzenli et al. (2017) suggested that design educators need to produce information through original methods and share them with all design trainers. A contribution to the teaching-learning process by an experimental method has been revealed in this study.

- Boucharenc (2006) indicated that basic design principles are still relevant in contemporary design education. Thus, a term assignment dealing with interpretation of a movie though basic design principles has been examined.

- Basic design education is the effort of expressing the abilities and power of creativity in aesthetic level and is the transfer of thinking, emotions and impressions of students (Beşgen, Kuloğlu, \& Fathalizadehalemdari, 2015). It has been reconfirmed that students' cognition, observation, ways of access to information and creativity are determinant in 
transforming intangible knowledge into tangible practice.

\section{Conclusion}

Transformation of intangible concepts into tangible products requires quite attention. Students are leaded to research and learn the techniques which they can use in all kinds of arrangements; through applied studies and visual language. Visual language diversity can be seen in the products of the case study (Figure 4). Because of the visual memory has strong effects, a designer should always make careful examination and observation around her/his living environment. Thus, creative ideas should come to light due to inferences and selective perception; which can also be gained during basic design education. Within the method (Figure 2) of this case study:

- Students developed their observation and examination ability. By watching the same movie, they made unique observations and gained visual perceptions.

- Inspiring from the movie, students achieved an improvement of creative thinking through cognition in design process.

- Production of various three-dimensional design outcomes related to the movie has put forward the interpretation diversity.

\section{References}

Alsaggar, M. A., \& Al Atoum, M. S. (2019). The image as a method of teaching in art education. Gazi University Journal of Science Part B: Art, Humanities, Design and Planning, 7(2), 211-221.

Atik, D. (2020). An evaluation experience for interpretation diversity of basic design products. International Refereed Journal of Design and Architecture, 20, 97-127.

Aydinl1, S. (1996). An approach to architectural education based on hermeneutical understanding. ACTA Politechnica Scandinavia, 105, 97-101.
Aypek Arslan, A. (2012). An analysis of teaching methods used at the course of basic design. Procedia - Social and Behavioral Sciences, 51, 172-176.

Beşgen, A., \& Köseoğlu, Ş. (2019). Sinemamimarlık arakesitinde bir mekana dokunmak: Sine-tasarım atölyesi. SineFilozofi, 26-52.

Beşgen, A., Kuloğlu, N., Fathalizadehalemdari, S. (2015). Teaching / learning strategies through art: Art and basic design education. Procedia - Social and Behavioral Sciences, 182, 428-432.

Bostancı, B., Akbulak, B., \& Akgül Yalçın, E. (2016). The transformation of music into form: basic design education in architecture. Abant İzzet Baysal Üniversitesi Eğitim Fakültesi Dergisi (İpekyolu Özel Sayısı), 16, 2196-2207.

Boucharenc, C. (2006). Research on Basic Design Education: An International Survey. International Journal of Technology and Design Education, 16, 1-30. doi:10.1007/s10798-0052110-8

Canbakal Ataoğlu, N. (2015). Basic design, theory and practice. Procedia-social and Behavioral Sciences, 197, 2051-2057.

Düzenli, T., Alpak, E. M., \& Özkan, G. D. (2017). Effects on learning and creativity of basic design course in landscape architecture. Electronic Journal of Social Sciences, 16(64), 1450-1460.

Ertok Atmaca, A. (2014). Temel tasarım. Ankara: Nobel Akademik Yayıncılık Eğitim Danışmanlık Tic. Ltd. Şti. .

Eysenck, H. J. (1994). The measurement of creativity. In M. A. Borden (Ed.), Dimensions of Creativity (pp. 199-242). Cambridge: MIT Press.

Kavas, K. R., Erbaş, İ., \& Danacı, H. M. (2016). A reinterpretation of the suprematist painterly space for the comprehension of basic design in 
architectural education. Journal of Human Sciences, 13(3), 5813-5825.

Ketizmen Önal, G. (2011). Architectural design process in creativity and cultural schema. Uludağ Üniversitesi Mühendislik-Mimarlık Fakültesi Dergisi, 16(1), 155-162.

Onur, D., \& Zorlu, T. (2017). Tasarım stüdyolarında uygulanan eğitim metotları ve yaratıcılık ilişkisi. The Turkish Online Journal of Design, Art and Communication, 7(4), 542555.

Pallasmaa, J. (2008). 112020 tarihinde http://v3.arkitera.com/g143-sinema-vemimarlik.html year=\&aID=2621 adresinden alınd 1

Pazarlığlu Bingöl, M. (2016). Temel tasarım eğitiminde kavramdan üç boyuta geçişe yönelik bir uygulama örneği. İdil Dergisi, 21(5), 339362.

San, İ. (2010). Sanat eğitimi kuramları. Ankara: Ütopya Yayınevi.

Seylan, A. (2005). Basic design. Ankara: Dağdelen Publishing.

Smith, S. M., Ward, T. B., \& Finke, R. A. (1995). Creative cognition approach. Cambridge: MIT Press.

Soliman, A. M. (2017). Appropriate teaching and learning strategies for the architectural design process in pedagogic design studios. Frontiers of Architectural Research, 204-217.

Spaihts, J. (Writer), \& Tyldum, M. (Director). (2016). Passengers [Motion Picture].

Tanyeli, U. (2001). Sinema ve Mimarlık , Temsiliyet / Nesnenin Temsili, Sanatın Sanallıkla İfadesi. Arredamento(11), 66.

URL 1. (2020). Retrieved from https://en.wikipedia.org/wiki/Passengers_(201 6_film)) at 082020
URL 2. (2020). Retrieved from https://www.imdb.com/title/tt1355644/ at 08 2020.

URL 3. (2020). Retrieved from https://www.amazon.com/Passengers-Blu-rayJennifer-Lawrence/dp/B01LTI0BPU at 11 2020.

URL 4. (2020). Retrieved from https://www.overthinkingit.com/2017/01/03/m orality-passengers-part-2/ at 082020.

Yürekli, İ., \& Yürekli, H. (2004). Mimari tasarım eğitiminde enformellik. İTÜ Dergisi / A Mimarlık Planlama Tasarım, 3(1), 53-62.

Zülfikar, H. C., \& Ertin, D. G. (2014). A case study in design education: Creative drama method with image. Global Journal of Arts Education, 4(2), 43-48. 